\title{
A Case Study on Week without Walls (WWW) in UiTM Negeri Sembilan: Critical Reading and Creative Writing beyond the Second Language Classrooms
}

\section{Wan Zumusni Wan Mustapha, Mohd Nur Fitri Mohd Salim, Irma Ahmad, and Sheela Paramasivam}

Academy of Language Studies, UiTM Negeri Sembilan, 70300 Seremban, Negeri Sembilan, Malaysia

\section{Abstract}

Teaching and learning critical reading and creative writing in the second language have gone beyond the four walls of classrooms and language classrooms. Apart from flipped classrooms, where lessons and assignments can be conducted and done during weekends, public holidays and festive breaks, Universiti Teknologi MARA has moved another step in implementing Week without Walls (WWW) where students learn

Corresponding Author: Wan Zumusni Wan Mustapha zumusni178@uitm.edu.my

Received: 1 July 2019

Accepted: 18 July 2019

Published: 31 July 2019

Publishing services provided by Knowledge E

(c) Wan Zumusni Wan Mustapha et al. This article is distributed under the terms of the

Commons Attribution License,

which permits unrestricted use and redistribution provided that the original author and source are credited.

Selection and Peer-review under the responsibility of the AICLL 2019 Conference Committee. in a less structured way outside the classrooms. Qualitative method namely case study is used to design the research methodology for this study. The focus on the case study is to see how learning is demonstrated through the use of social media. The case study on diploma and degree students from three faculties found that WWW has increased motivation and interest in teaching and learning of second language reading and writing. Other than using the usual teaching videos, notes on the online platform, students are asked to read Reader's Digest magazines and post a caption of an interesting article or activity they have read on the social media. Using social learning theory, analysis of the students' narratives on social media postings reveal that given the freedom to demonstrate their learning experience, students can be creative by posting pictures and videos of what they have read on their social media and realize that learning is not just for assessments.

Keywords: week without walls, learning beyond the classroom, second language, social media, social learning theory

\section{Introduction}

UiTM Negeri Sembilan, Seremban Campus offers English courses to diploma and degree students from Faculty of Computer Science and Mathematics, Faculty of Sport Sciences and Faculty of Science Administration and Policy. These diploma and degree students take English courses in Semester 1 until Semester 4. The contact hours for the diploma students are 4 hours, two hours for each class and two hours for degree 
followed by a week of study leave before the final examination which normally takes three to four weeks.

Throughout the semester, there will be four to six weeks of blended learning sessions where students access the lessons on an online platform known as i-learn. The blended learning weeks uses the flipped classroom principle (Fulton, 2012) to allow self-paced learning. Of late, there is a shift from final examinations to ongoing assessments which are conducted during the semester. The last two semesters have seen a new approach introduced in the middle of the semester, namely Week Without Walls (WWW). During this week, lecturers are given the flexibility to allow second language learning and teaching outside the classrooms.

From Week three of the semester, students are on blended learning study mode, other than face-to-face classroom instructions. During this blended learning sessions, students access the teaching materials in the forms of PowerPoint notes and videos on $\mathrm{i}$ learn. The teaching materials correspond with the syllabus of the particular course. Apart from the prescribed textbooks for the respective diploma and degree courses, students are also required to read Reader's Digest magazines and write in their respective journals. They are encouraged to reflect on the stories that they have read, or take note of the new vocabulary that they have learned.

This paper shares how Reader's Digest magazines are used outside ESL classrooms during the Week Without Wall where students are asked to read Reader's Digest magazine, as the authentic reading material and share their reflection and reading experience on the social media. The out-of-class activities are done to spice up the reading and writing activities by giving students options to display their learning experience creatively in a manner they enjoy most.

\section{Literature Review}

One of the challenges for educators in second language at schools and higher education institutions is to create a fun, engaging and motivating reading program for second language learners. This means to prepare students not only to do well in examinations but also to be lifelong learners. Heavy dependence on the reading textbook make students struggle to understand the English language textbooks and they might find the textbooks irrelevant, uninteresting, and culturally unfamiliar. More importantly, acculturating reading for pleasure would help to combat social exclusion and raise educational standards (Department of Education UK, 2017). 
The social learning theory explains human behavior as a result of their interaction with their environment and other people from cognitive, behavioral and environmental determinants (Walther, 1992). Outdoor learning activities have an influential and effective impact on students' academic performance on learning as reported by Dhanapal's (2013) study on students' enthusiasm on learning science outdoor. Therefore, organizing an outdoor reading activity using Reader's Digest magazine can also increase motivation to read the magazine. Kelly et al. (2002) and Polio (2014) propose effective ways for teachers to choose and use authentic materials with ESL/EFL students. This can be done by doing reading and writing activities outside the classroom involving teamwork and collaborative learning, in an outdoor setting with friends and family members.

Biggs and Tang (2007) argued that the most important aspect of courses is they should be "constructively aligned", where students demonstrate the desired learning outcomes. Due to the positive reviews on flipped classroom approach (Butt, 2014), there is a high support for student-centered learning such as active learning and outdoor education.

\section{Research Method}

Qualitative method namely case study is used to design the research methodology for this study. The focus on the case study is to see how learning is demonstrated through the use of social media. Students who participate in this WWW are 39 diploma students from the Faculty of Computer Science and Mathematics in UiTM Seremban campus. They are in their second semester of their studies. During the WWW session, students are asked to take pictures and videos documenting their reading activities outside the classrooms. Reader's Digest magazine is used because using authentic reading materials also motivate learners to communicate and prepare learners for real world communication (Lansford, 2014). These students are allowed to be as creative as possible and add a caption to the pictures and videos. Those postings are shared on the social media such as Instagram and Facebook page are used as evidence on their learning experience to demonstrate their learning experience. This postings are also analyzed using the social learning theory after tabulating the captions and descriptions of the captions.

The sampling technique used in this study is convenience sampling. The selection of samples was made from the students' postings in the social media. For the purpose of this study, Facebook and Instagram are used as the platform to collect the samples from the students. The data collected in this study does not represent the entire population 
of students of UiTM Negeri Sembilan. However, it can be a starting point for future studies.

\section{Result and Discussion}

Analysis of students' narratives and social media postings reveal their creativity and engagement not only with the authentic reading materials but also with people around them (See Appendix). Students are enthusiastic to be given the freedom and creativity to express and share their learning experience as seen posted on the FB page https: //www.facebook.com/CReWRD/. The background for postings are found not only at home, hostel but also in the nature as long as it fits the week without wall theme, that is reading beyond the English Language classrooms. Some students posted the pages of the magazines that they were reading. Some students came out with captions and videos to reflect on their learning activity and some let the pictures speak for them. Appendix B shows the captions written by the students in the social media postings and how it is posted either the magazine itself, the students' picture or their pictures with family members such as their mother, father or friends.

Most postings come with hashtags and some comes with simple and catchy captions such as

A well-written novel can transport you to other realms, while an engaging article will distract you and keep you in the present moment, letting tensions drain away and allowing you to relax

\#weekwithoutwalls

\#uitms3ns

\#readersdigestmagazine

A caption can be a simple sentence such as

Start our day's with a positive vibes

\#weekwithoutwalls

\#uitms3

\#readersdigest

Chih-Hsiung (2000) posits that social learning requires cognitive and environmental determinants to enhance on-line social interaction. In UiTM context, WWW can complement Blended Learning which is practiced four to six weeks during the semester for the undergraduate students. 


\section{Conclusion}

Integrating critical reading and creative writing using authentic reading materials such as Readers' Digest during WWW in UiTM as well as using the social media has indeed motivated students to learn beyond the confines of the second language classrooms. Before posting anything on the social media, students have to read and think of the best captions to their pictures and videos. This requires some cognitive and behavioural work as students take their social presence on the social media seriously. When applied in second language learning instruction, social presence in the social learning experience can be a critical factor for motivation and learning retention. Further studies can include analysis of the students' choice of background and social media postings.

Other than learning engagement in constructing meanings and learning new knowledge from the magazines, WWW gives positive second language learning experience to the undergraduate students. In addition, higher social presence will lead to the retention process of social learning (Chih-Hsiung, 2000) as supported by Bandura and Vygotsky's works. The dynamics of social presence can be further analysed in how student learning can be applied in socio-cultural learning context and interactivity with the learning texts. Further studies can be done to see the changes in the social interactions between actors and social networks to get a clearer picture on how social learning impacts students' second language learning outcomes.

\section{Acknowledgements}

The authors would like to thank Universiti Teknologi MARA for implementing Week without Wall and Reader's Digest Asia Pacific for supporting the reading program for universities and schools particularly in Universiti Teknologi MARA, Negeri Sembilan campus.

\section{Appendices}


Appendix A Students' postings on social media
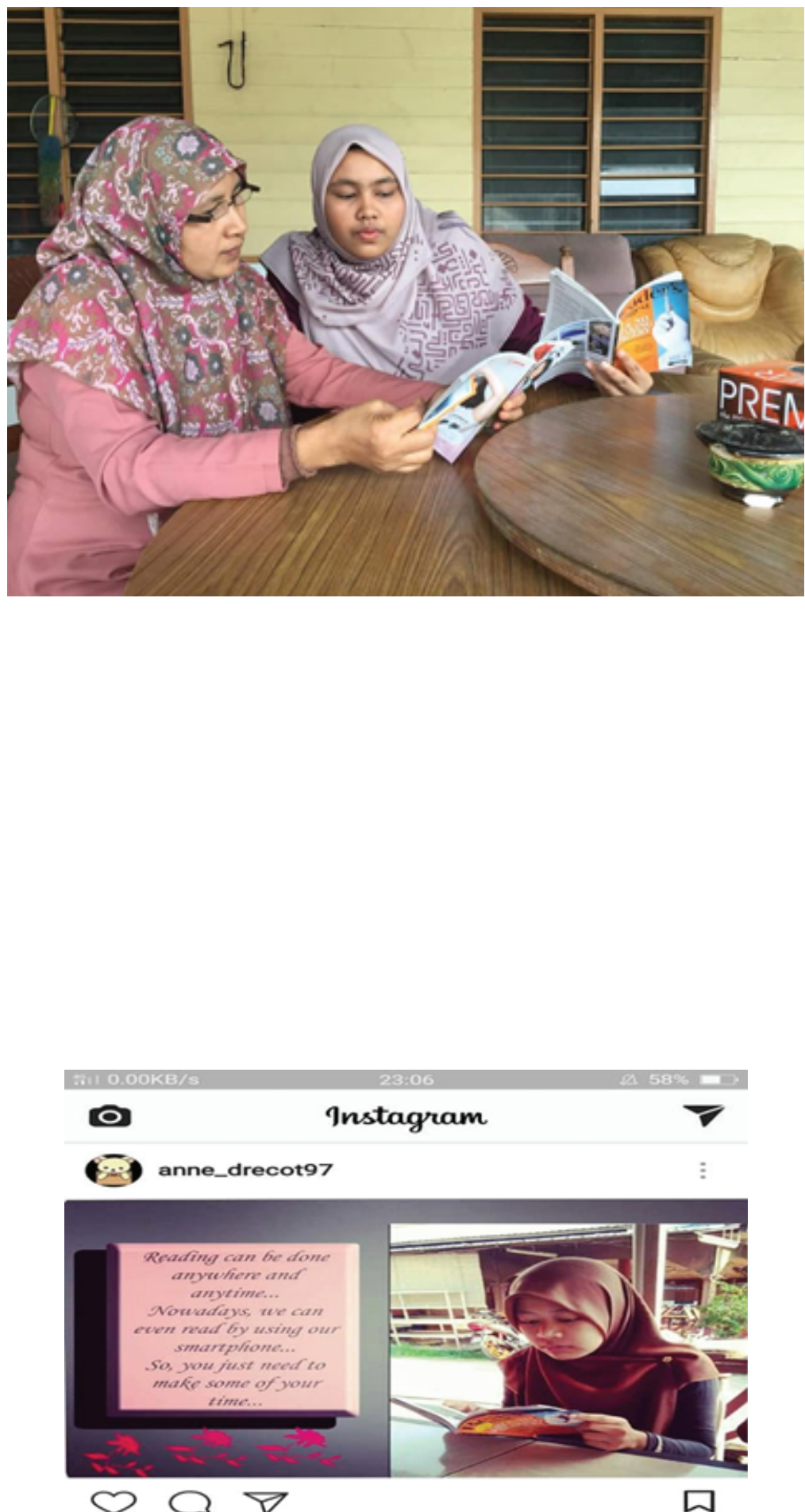

ロ

anne_drecot97 While waiting for breakfast... Let's read readersdigest $\sim$ and spend our time with family on holiday

\#weekwithoutwalls

\#uitms3

\#readersdigest

17 SECONDS AGO

T:

2.0 amirah painudinnt 


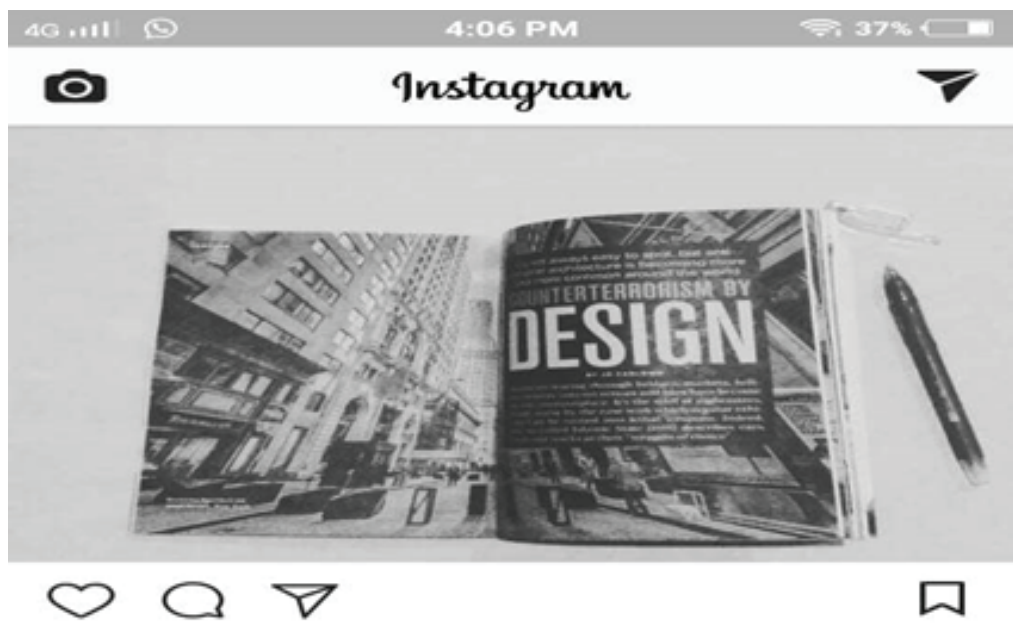

ilman_apek Reading increases vocabulary and intelligence in the same time boosts up our brain power. It helps us to relax and reduce stress while improving analytical thinking, memory also writing skills.

What else do you want?

\#weekwithoutwalls

\#uitms3ns

\#readersdigestmagazines

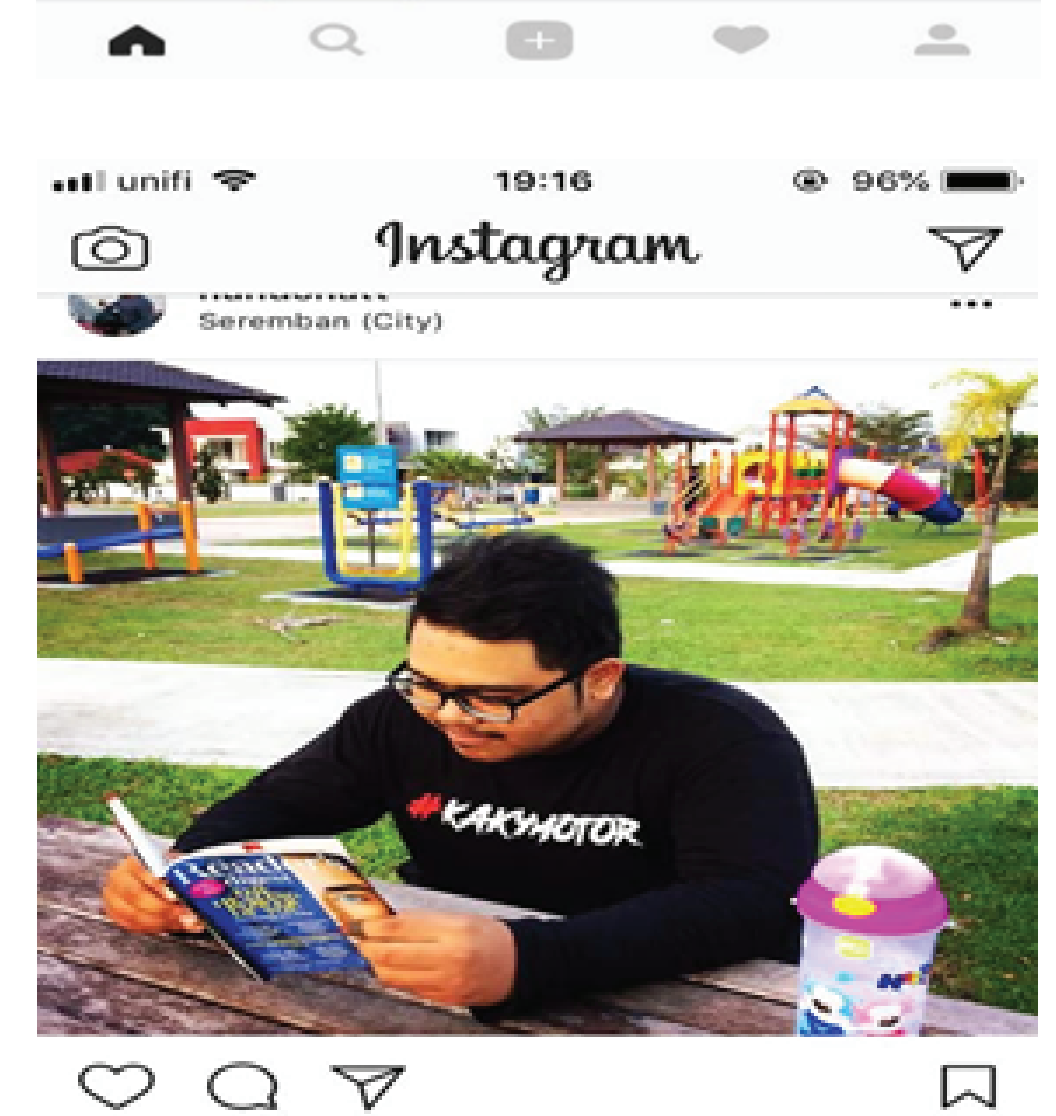

nundonatt "There is no friend as loyal as a book." - Ernest Hemingway

Hweekwithoutwalls

\#uitmseremban3

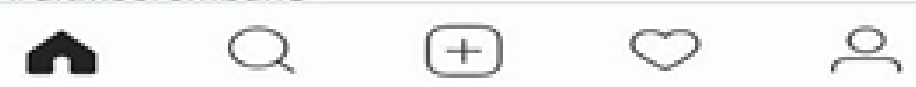




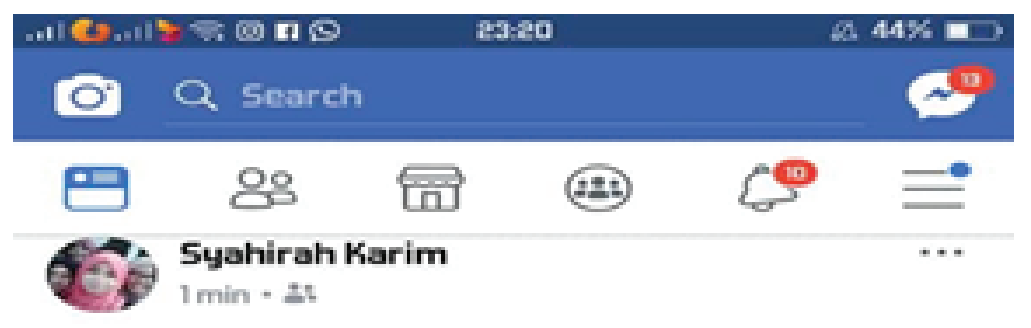

\begin{abstract}
A well-written novel can transport you to other realms, while an engaging article will distract you and keep you in the present moment, letting tensions drain away and allowing you to relax Atweekwithoutwalls \#uitms3ns \#readersdigestmagazines
\end{abstract}

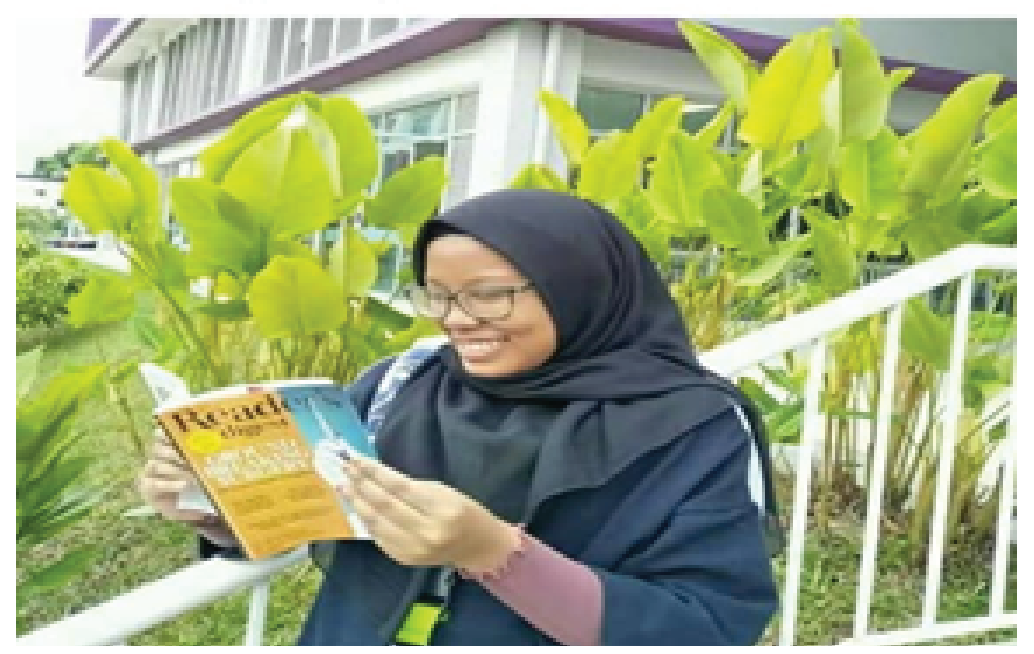

Appendix B Analysis of the captions on Instagram as shared on FB Page https://www.facebook.com/CReWRD/

\begin{tabular}{lll} 
NO CAPTIONS & $\begin{array}{l}\text { DESCRIPTION OF THE } \\
\text { POSTED PICTURE }\end{array}$ \\
1. & $\begin{array}{l}\text { March } 2018 \text { Edition } \\
\text { \#weekwithoutwalls } \\
\text { \#uitms3 } \\
\text { \#readersdigest }\end{array}$ & Self-portrait \\
2. $\quad \begin{array}{l}\text { \#weekwithoutwalls } \\
\text { \#uitms3ns } \\
\text { \#readersdigestmagazines }\end{array}$ & Self-portrait \\
3. No caption & $\begin{array}{l}\text { Pictures of mother and } \\
\text { daughter }\end{array}$ \\
4. $\quad \begin{array}{l}\text { Start our day's with a positive vibes } \\
\text { \#weekwithoutwalls }\end{array}$ & Self-portrait \\
\#uitms3 & \\
\hline \#readersdigest &
\end{tabular}


NO CAPTIONS

DESCRIPTION OF THE POSTED PICTURE

5. While waiting for breakfast...Let's read readersdigest $\sim$ and spend our time with family on holiday

Self-portrait with a picture of quote

\#weekwithoutwalls

\#uitms3

\#readersdigest

6. \#weekwithoutwalls

Self-portrait

\#uitms3

\#readersdigest

7. So I have been struggling with calculation these two days, I Magazine only think I should play with some words

\#weekwithoutwalls

\#uitms3ns

\#Reader'sDigestmagazines

8. Reader's Digest $<3$

Self-portrait

9. While waiting for my food

Self-portrait

\#ELC501

\#weekwithoutwalls

\#uitms3

\#readersdigest

10. Bila kau rasa lelahnya belajar, maka kau akan rasa peritnya

Self-portrait kebodohan : imam as syafie Keep reading untill you successfu

\#uitms3

\#weekwithoutwalls

\#readersdigest

\#wanzumusni

NO CAPTIONS

\section{PICTURE}

11. Read before you think To gain more let's read readers digest. Magazine only Go and grab yours at the nearest bookstore

\#weekwithoutwalls

\#uitms3

\#readersdigest

\#elc501

12. Reading increases vocabulary and intelligence in the same time Magazine only boosts up our brain power. It helps us to relax and reduce stress

while improving analytical thinking, memory also writing skills

What else do you want?

\#weekwithoutwalls

\#uitms3ns

\#readersdigestmagazines

13. "There is no friend as loyal as a book."-Ernest Hamingway \#weekwithoutwalls

\#uitmseremban3

14. Gonna read reader's digest! The more that you read, the more Magazine and self-portrait things you will know.

\#weekwithoutwalls

\#uitms3ns

\#readersdigestmagazines

15. You can find magic wherever you look. Sit back and relax, all Magazine only you need is book.

\#weekwithoutwalls

\#uitms3ns

\#readersdigestmagazines 
NO CAPTIONS

16. "When 'l' is replaced by 'WE' even Illness becomes Wellness" \#weekwithoutwall \#uitms3 \#readersdigest

17. the more that you read. the more things you will know. the more Self-portrait with a picture that you learn. the more places you'll go.

18. \#weekwithoutwalls of quote

\#uitms3ns

Self-portrait

\#readersdigestmagazines

19. By reading, phantasy is created.

\#weekwithoutwalls

\#uitms3ns

\#readersdigestmagazines

20. Never trust anyone who has not brought a book with them. So Self-portrait trust me okay? Hehe pi pantai bawak Reader's Digest.

\#weekwithoutwalls

\#uitms3

\#readersdigest

21. Chillin'

\#weekwithoutwalls

\#uitms3ns

\#readersdigestmagazines

22. There can be miracles when you believe. Though hope is frail, Self-portrait it's hard to kill. P/S: Read a book doesn't make you a nerd but it make you smarter and obviously it helps you to escape reality. \#weekwithoutwalls

\#uitms3ns

\#readersdigestmagazines

23. Science is showing that how you feel isn't just about what you Self-portrait eat or do you think. It's about what you believe.

\#weekwithoutwalls

\#uitms3

\#readersdigest

24. "reader's digest"

\#weekwithoutwalls

\#uitms3ns

\#readersdigestmagazines

25. \#weekwithoutwalls

\#uitms3ns

\#Reader'sDigestmagazines

26 The more that you read, the more things you will know, the Self-potrait more that you learn, the more places that you will go.

27 Reading reader's digest during free time. Interesting article Self-potrait about Futuristic Hotel Room

\#weekwithoutwalls

\#uitms3ns

\#reader'sdigestmagazine

28 A well-written novel can transport you to other realms, while an Self-potrait engaging article will distract you and keep you in the present moment, letting tensions drain away and allowing you to relax \#weekwithoutwalls

\#uitms3ns

\#readersdigestmagazine 


\begin{tabular}{|c|c|c|}
\hline NO & CAPTIONS & PICTURE \\
\hline 29 & $\begin{array}{l}\text { \#weekwithoutwalls } \\
\text { \#uitms3 } \\
\text { \#readersdigestmagazine }\end{array}$ & Self-potrait \\
\hline 30 & $\begin{array}{l}\text { "Find the knowledge that a good book is awaiting me at the end } \\
\text { of a long day makes that day happier"-Kathron Noris } \\
\text { \#weekwithoutwalls } \\
\text { \#uitms } 3 \\
\text { \#readersdigestmagazine }\end{array}$ & Self-potrait \\
\hline 31 & $\begin{array}{l}\text { I really love reading..serious } \\
\text { \#weekwithoutwalls } \\
\text { \#uitms3 } \\
\text { \#readersdigestmagazine }\end{array}$ & Self-potrait \\
\hline 32 & $\begin{array}{l}\text { \#weekwithoutwalls } \\
\text { \#uitmseremban3 } \\
\text { \#readersdigestmagazine }\end{array}$ & Self-potrait \\
\hline 33 & $\begin{array}{l}\text { Reading is good to increase your knowledge } \\
\text { \#weekwithoutwalls } \\
\text { \#uitms3 } \\
\text { \#readersdigest }\end{array}$ & Self-potrait \\
\hline 34 & $\begin{array}{l}\text { \#weekwithoutwalls } \\
\text { \#uitms3 } \\
\text { \#readersdigest }\end{array}$ & Self-potrait \\
\hline 35 & $\begin{array}{l}\text { \#weekwithoutwalls } \\
\text { \#uitms3 } \\
\text { \#readersdigest }\end{array}$ & Self-potrait \\
\hline 36 & $\begin{array}{l}\text { \#weekwithoutwalls } \\
\text { \#uitms3 } \\
\text { \#readersdigest }\end{array}$ & Self-potrait \\
\hline 37 & $\begin{array}{l}\text { \#weekwithoutwalls } \\
\text { \#uitmseremban3 } \\
\text { \#readersdigest }\end{array}$ & Self-potrait \\
\hline 37 & $\begin{array}{l}\text { \#weekwithoutwalls } \\
\text { \#uitms3 } \\
\text { \#readersdigest }\end{array}$ & Self-potrait \\
\hline 38 & $\begin{array}{l}\text { "if you don't like to read, you haven't found the right book" J.K } \\
\text { Rowling } \\
\text { \#weekwithoutwalls } \\
\text { \#uitmseremban3 } \\
\text { \#readersdigestmagazine }\end{array}$ & Self-potrait \\
\hline 39 & $\begin{array}{l}\text { My favourite part in reader's digest } \\
\text { \#weekwithoutwalls } \\
\text { \#uitmseremban3 } \\
\text { \#readersdigestmagazine }\end{array}$ & Magazine \\
\hline
\end{tabular}

\section{References}

[1] Bandura, A. (1977). Social Learning Theory. Englewood Cliffs, NJ: Prentice-Hall

[2] Butt, Adam. (2014). Students' views on the use of a flipped Classroom approach: Evidence from Australia. Business Education and Accreditation. 6 (1). 33-44. 
[3] Department of Education (2017). Unlocking talent, fulfilling potential. A plan for improving mobility through education. https://assets.publishing.service. gov.uk/government/uploads/system/uploads/attachment_data/file/667690/ Social_Mobility_Action_Plan_-_for_printing.pdf

[4] Dhanapal, S. and Lim, C.C.Y. (2013). A Comparative study of the impacts and students' perceptions of indoor and outdoor learning in the science classroom. Asia-Pacific Forum on Science Learning and Teaching. 14(2), Article 2, p.1.

[5] Fulton, K. (2012). Upside down and inside out: flip your classroom to improve student learning. Learning and Leading with Technolgy. 39 (8). 12-17.

[6] Gravetter, F.J.\& Forzano, L.A. (2009). Research methods for the Behavioral Science. 3rd Ed., Wadsworth, Cengage Learning.

[7] Gunawardena, C.N. \& Zittle, F. J. (1997). Social presence as a predictor of satisfaction within a computer-mediated conferencing environment. The American Journal of Distance Education, 11 (3), 8-26.

[8] Lansford, L. (2014). Authentic Materials in the classroom: The Advantages. Cambridge Conversations. http://www.cambridge.org/elt/blog/2014/05/16/ authentic-materials-classroom-advantages/

[9] Walther, J.B. (1992). Interpersonal effects in computer-mediated interaction: A relational perspective. Communication Research 19(1), 52-90.

[10] Wan Zumusni WM, and Sheela, P. (2018). Propagating Critical Reading and Creative Writing Literacy Using Reader's Digest Magazines. Proceedings of the $1^{\text {st }}$ Annual International Conference on Language and Literature, 18-19 April 2018, Fakultas Sastra, UISU, Medan, Indonesia. Retrieved from: http://aicll.sastra.uisu.ac.id/index. php/aicll/article/view/41

[11] Vygotsky, L. S. (1978). Mind in Society. Cambridge, MA: Harvard University Press. 